Institute of $\mathbf{F}_{\text {ood and }} \mathbf{A}_{\text {gricultural }} \mathbf{S}_{\text {ciences }}$

\title{
Grandparents Raising Grandchildren: Understanding Relationships - Part $1^{1}$
}

Millie Ferrer, Angela Falcone, and Joe Pergola ${ }^{2}$

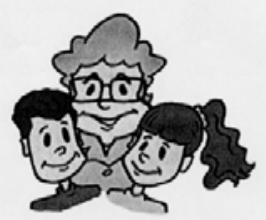

Goal: To provide grandparents with information to better understand family relationships.
Accepting your feelings and finding someone trustworthy to talk with will make you feel better. This can help you accept the things you cannot change. Remember that you are not alone. Other grandparents experience similar concerns. The following are some reflections shared by grandparents raising grandchildren.
Becoming a parent again can bring lots of joy and happiness. It can also bring other feelings too. Many grandparents raising their grandchildren describe feelings of:

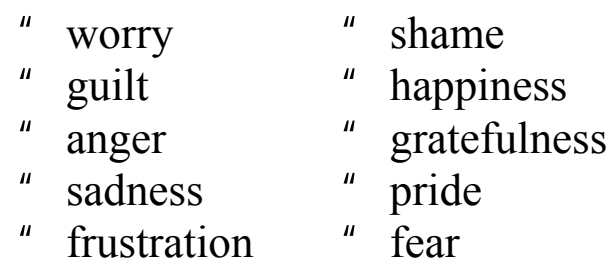

What feelings about your situation are you experiencing right now? Check the feelings you are experiencing.

\section{Grandparents:}

"I'm grateful I'm able to provide for my grandchild."

"I feel guilty about where I went wrong in raising my own children."

"I'm angry that I have to change my lifestyle and sacrifice personal needs and goals to care for my grandchildren."

"I feel sad that my grandchildren have been neglected."

"I am ashamed of my adult child's failure as a parent due to alcohol and drug abuse."

1. This document is FCS 2190-Eng, one of a series of the Department of Family, Youth and Community Sciences, Florida Cooperative Extension Service, Institute of Food and Agricultural Sciences, University of Florida. Publication date: January 2002. Reviewed by Anne Fugate, Project Coordinator, University of Florida, for Florida's CYFAR State Strengthening Grant, Maisie Ross, Extension Agent III, and Stephanie Toelle, Extension Agent III. Thanks to Erica Murphy, UF undergraduate student, for her support and assistance. Please visit the EDIS Web site at http://edis.ifas.ufl.edu

2. Millie Ferrer, Ph.D., Associate Professor, Human Development, Angela Falcone, Ed.S., Graduate Assistant, and Joe Pergola, M.S., Extension Agent IV, Department of Family, Youth and Community Sciences, Cooperative Extension Service, Institute of Food and Agricultural Sciences, University of Florida, Gainesville, 32611.

The Institute of Food and Agricultural Sciences is an equal opportunity/affirmative action employer authorized to provide research, educational information and other services only to individuals and institutions that function without regard to race, color, sex, age, handicap, or national origin. For information on obtaining other extension publications, contact your county Cooperative Extension Service office. Florida Cooperative Extension Service / Institute of Food and Agricultural Sciences / University of Florida / Christine Taylor Waddill, Dean 


\section{Lifestyle Changes}

Sometimes life events do not happen the way we plan. You probably never expected that one day you would be raising your grandchild. As you take on this new role, there will be many changes in the relationships you have with family, friends, and yourself. Often, life crises provide us with an opportunity for growth. These times can bring out the best in us as we rise to new challenges. In order to learn from this crisis, you need to realize how your new role affects your relationships. Let's take a look at your relationships before and after you started raising your grandchild.

\section{Relationship with Family and Friends}

\section{Partner}

Before taking on this new responsibility, you probably spent a lot more time with your partner. Clearly, it will be hard to continue to build this relationship while

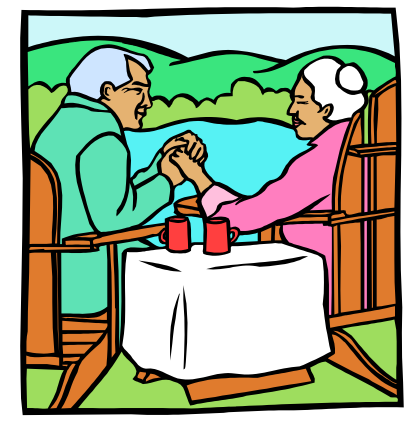
spending less time together. Yet, if both of you are committed to raising your grandchild, your positive influence will strengthen your family unit. Mutual support during this new challenge can also bring you closer together as a couple. How has your relationship with your partner changed?

\section{Adult Child}

As a result of parenting your grandchild, you may experience changes in your relationship with your adult child. Whether your new role was planned or has resulted from a crisis, a change in your relationship is bound to happen. You now have added responsibilities. You may also experience mixed feelings depending on your situation.

How has your relationship with your adult child changed?

\section{Grandchild}

Before taking on the role of a caregiver, you did not have as many responsibilities. Upon accepting this new role, you may be uncertain of how

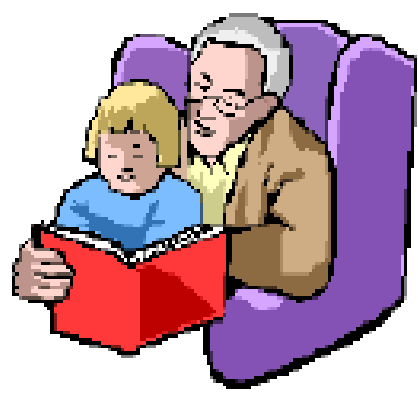
to parent your grandchild. Also, your grandchild may not be sure of what to expect from you. It is important for both of you to talk about these feelings. By talking you will develop a closer relationship. Research has shown that children who have a meaningful relationship with an important adult role model are more likely to overcome their hardships. What thoughts and feelings do you think your grandchild is experiencing as a result of this new family structure?

\section{Friends}

With your new role as a parent, you may not have as much time to spend with old friends. Perhaps, as a result of your new role, you may also discover that you no longer share the same interests. On the other hand, you may be able to meet new friends that share the same challenges you are facing. Finding and keeping friends who support and comfort you during these times is extremely important. How have your old relationships changed? 


\section{$\underline{\text { Relationship with Self }}$}

Many people overlook the importance of selfcare. But, if you don't take care of yourself, all of your efforts to care for others will be in vain. There are many things that will require your best physical and mental well-being:

- coping with changing relationships

- parenting your grandchild

- maintaining and seeking support from others

- locating and using appropriate resources

- dealing with the legal system

Each of us have our own ways of dealing with stress. How do you take care of yourself during these challenging times?

Now that you have become aware of the changes in your relationships, let's take a look at what makes relationships strong and healthy. Described below are some characteristics that are important in creating healthy family relationships. As you read through the definitions, think of how these characteristics relate to your family. In the next publication (Building Relationships Part 2 ), you will learn ways of enhancing these traits.

\section{Characteristics of Strong Families}

\section{Defined Set of Beliefs and Values}

Beliefs and values make you who you are. They are what you hold dear and what you believe is right for your family. They are created by the experiences you've had in life and help guide you through life.
Different families value different things. For example, one family may value having dinner together and, therefore, have a family rule of eating dinner together. If the child misses dinner, the family is likely to be upset because the child didn't respect the family's value and rule. But another family may not think this time together is important and is likely not to be upset if the child misses dinner. This family may have an unspoken rule that family members can eat dinner whenever and wherever they want.

Your decision to take care of your grandchild shows you value family unity. Another value you may hold dear is commitment. Families who invest time and energy into creating and sustaining healthy relationships show commitment. They support each other and believe that family comes first. They also know they can depend on and trust each other. The following are other beliefs and values:

- loyalty

- honesty

- time together

- family traditions

- respect for others

- a positive outlook

- spirituality/religion

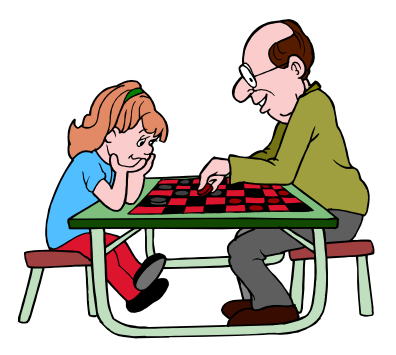

- following through on promises

- sticking together during rough times

Name three beliefs or values you consider most important for your family.

1.

2.

3. 


\section{Healthy Boundaries}

Boundaries are the limits you set in your relationships. They play an important role in building and maintaining relationships. As a grandparent, you are the authority figure. Part of your role is to set clear, appropriate boundaries for your grandchild.

Boundaries can help you

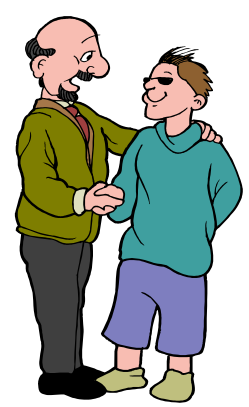
establish a clear relationship with your grandchild. At the same time, they can help you deal with such issues as discipline. Without clear-cut boundaries, your grandchild may overstep the limits you want to establish. With clear boundaries, your grandchild knows what is expected and, therefore, feels secure in his* world.

When a child feels secure he is able to explore and take risks necessary to grow physically, mentally, socially, and emotionally. Healthy boundaries need to be established when sharing feelings, setting expectations, and giving choices to your grandchild.

\section{Sharing feelings}

Depending on the age of your grandchild, share with him why you are happy, sad, or angry. Children need to learn how to handle feelings. You will be your grandchild's role model for how he handles different life situations. However, though it is appropriate to share feelings with your grandchild, it is inappropriate to treat him as your best friend by telling him adult details. For example, you might be angry with your spouse. If your grandchild asks you what is wrong, you could share with him that you had a disagreement with his grandfather. However, do not give intimate details of your argument.

\section{Setting expectations}

Having age-appropriate rules is important in establishing good boundaries. To set appropriate rules, you must understand your grandchild's stages of development (see publications on Understanding and Guiding Your Grandchild's Behavior Part 1 \& 2). If you set a rule that is beyond their level of understanding, you will set them up for failure. For example, you might expect your grandchild, age 2, to sit quietly without causing disruptions while waiting at the local health center. It's not practical to expect a toddler to sit quietly for any length of time. They are curious by nature and have short attention spans. It may be better to find child care while you run your errands. However, if you need to take him with you, bring along toys, activities, and snacks to make his and your time less frustrating.

\section{Giving choices}

Part of healthy

development is being able to make your own decisions. Children who are taught to make their own decisions feel better about themselves. They learn to be responsible. As the adult in charge, you need to know when to let your grandchild make his own decisions. You also need to know when to set boundaries for his decisions. We can start teaching children to make decisions early. For example, an ageappropriate choice would be asking your 6year-old grandchild if he would like to have spaghetti or a sandwich for lunch. Another 
age-appropriate decision is letting your 13year-old choose which school activities to be involved in. However, some decisions need to be made by you. These decisions may include acceptable bedtime, television programs, and curfew.

As your grandchild grows older, you need to let go and be willing to negotiate certain rules. Making decisions that affect our lives makes us feel more in control. When we feel more in control, it enhances our well-being.

\section{Ability to Adapt to Change}

Change is bound to happen. Families need to be flexible and learn to adapt to new situations. For example, the parenting strategies you use with your preschooler need to be different from the ones you will use when your grandchild becomes a teenager. You will create unnecessary conflict if you continue to use the same parenting strategies and are unwilling to change.

The ability to adapt to change has to do with your attitude and how willing you are to accept change. The way you confront these new changes will affect how satisfied you are in your new role.

\section{Good Communication}

Communication involves the exchange of words, ideas, and feelings between two people. It is what we say and how we say it. Healthy families strive for good communication. Yet, sometimes communication can be unclear and create misunderstandings among family members.
Good communication can be difficult when each family member has a different idea of how to communicate well. For example, a parent who constantly talks "at" her child by giving commands (e.g., "Clean your room") and lecturing (e.g., "Don't talk with your mouth full") may believe this is good communication. However, communication is more than giving commands and lecturing. It is best for a parent to talk "with" her child. Talking with a child means not only speaking to him but also listening to what he has to say. Families become stronger when they learn to communicate better.

There are specific skills that families can learn to improve their communication. These include:

( Talking with and listening to each other

( Speaking directly without blaming

( Having empathy for one another

( Sharing feelings

( Using humor

( Solving problems as a family

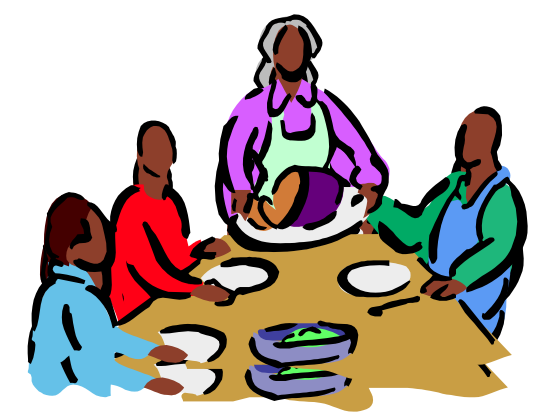

Many changes will occur in your life as you take on your new grandparenting role. Changes and challenges are not necessarily bad. All families have problems. What distinguishes healthy families from unhealthy families is that they have coping and problem solving skills. In the next publication, you will learn how to develop the skills to become a strong family. 
*This publication uses "he", "his", or "him" to represent children of both genders

\section{References:}

Olson, D.H., \& DeFrain, J. (1997). Marriage and the family: diversity and strengths. Mountain View, CA. Mayfield Publishing Co.

Schenck, B.R. (1997). Winning ways to talk with young children. University of Florida, Cooperative Extension. 10pp. FCS 2021.

Walsh, F. (1998). Strengthening family resilience. New York: Guilford Publication Inc. 